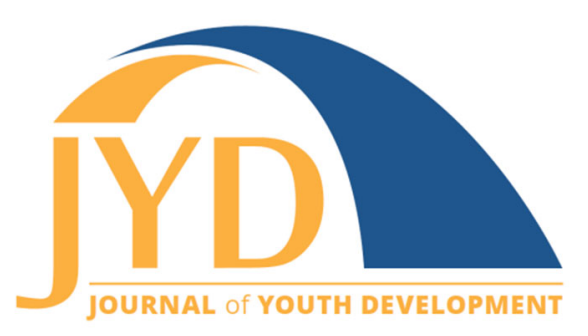

http://jyd.pitt.edu/ | Vol. 15 Issue 5 DOI 10.5195/jyd.2020.918 | ISSN 2325-4017 (online)

\title{
Resource Review: Clearinghouse for Military Family Readiness
}

\section{Kirk Bloir}

Ohio State University Extension 4-H Youth Development

bloir.1@osu.edu

\begin{abstract}
Youth-serving professionals have unique opportunities to help support military families in promoting positive youth development. The Clearinghouse for Military Family Readiness provides information, resources, and tools on effective programs and practices youth development professionals, schools, and communities can use to help support military families. It is a comprehensive, trusted, easy-to-navigate source of evidence-based and evidence-informed resources, technical assistance, and support that helps professionals who support military families do that work more effectively.
\end{abstract}

Key words: military families, readiness and resilience, military-serving professionals, military programing, program effectiveness

\section{Introduction}

Across the nation and around the world, more than 2.1 million men and women serve in the U.S. military (Defense Manpower Data Center, 2019). When dependents are included, the number jumps to 4.7 million, with 1.7 million being children (Department of Defense [DoD], 2018).

Given this large number, it is highly likely that military youth will be part of many classrooms, after-school programs, 4-H clubs, and faith-based congregations. Although most militaryconnected children and families are doing well, some struggle and others could benefit from greater support given the realities of military service (National Academies of Sciences, Engineering, and Medicine, 2019; Sullivan et al., 2019). Youth-serving professionals have unique opportunities to help support military families in promoting positive youth development

(cc) EY New articles in this journal are licensed under a Creative Commons Attribution 4.0 License. This journal is published by the University Library System, University of Pittsburgh and is cosponsored by the University of Pittsburgh Press. The Journal of Youth Development is the official peer-reviewed publication of the National Association of Extension 4-H Youth Development Professionals and the National AfterSchool Association. 


\section{Clearinghouse for Military Family Readiness}

while also working to help prevent and address potential problems among service members and their families (Ames et al., 2011; Clary \& Ferrari, 2015; Ferrari, 2015; Huebner, 2019).

When youth development professionals, schools, and communities come together to help support military families, service members are more likely to be mission-ready and achieve success (Hawkins et al., 2018; Mogil et al., 2019; National Academies of Sciences, Engineering, and Medicine, 2019). However, choosing a program from the thousands available can be overwhelming. Choosing an effective program can be an even greater challenge.

To help make identifying effective programs less daunting, the Clearinghouse for Military Family Readiness (Clearinghouse hereafter) provides tools and information on effective programs and practices for military-serving professionals. They also provide technical assistance and coaching.

\section{Clearinghouse Description}

The Clearinghouse is an applied research center that provides tools and information to strengthen military families. Their mission centers on developing trusting, collaborative relationships with partners to engage with U.S. military families to ensure they are supported by effective programs and practices.

Funding for the Clearinghouse is provided by the DoD through a partnership between USDA's National Institute of Food Agriculture (NIFA) and the Office of the Deputy Assistant Secretary of Defense for Military Community and Family Policy in cooperation with The Pennsylvania State University. The Clearinghouse provides their services to military-serving professionals at no cost because of grant funding provided by DoD and NIFA.

The Clearinghouse helps military family-serving professionals identify, select, implement, and evaluate evidence-based and promising programs, practices, and resources on a wide range of family life, parenting, and mental health issues. The website is its primary public interface.

\section{Background}

The Clearinghouse team consists of 55 interdisciplinary Penn State faculty, staff, and students. The large team indicates the breadth of applied research, resources, and associated supports they offer professionals who provide direct programming, services, and support to military families. 


\section{Website Features}

On the homepage, users will find information grouped in six main sections, in addition to the search feature. Brief descriptions of each section, presented thematically, follow.

General information about the Clearinghouse is presented on the homepage and repeated in the "About," "Services," and "Contact Us" sections. See Table 1 for an overview of each.

\section{Table 1. Clearinghouse Website General Information Sections}

\begin{tabular}{|c|c|}
\hline Website section & Brief description \\
\hline About & $\begin{array}{l}\text { "What does the Clearinghouse do?" and four subpages: } \\
\text { 1. Mission/Vision } \\
\text { 2. Partnerships - lists } 10 \text { partner organizations; there is no description of any of } \\
\text { the organizations, but URLs are provided. } \\
\text { 3. Team - lists the team members and a brief biographical information including } \\
\text { phone and email. Photos of the team members are provided and help create a } \\
\text { sense of community. Several team members do not have any biographical } \\
\text { information posted. The page has a different layout without links back to the } \\
\text { "About" organizational structure, so users need to use the browser's back } \\
\text { button. } \\
\text { 4. Employment - includes internship and assistantship opportunities. A link opens a } \\
\text { new browser window and takes users to the Penn State employment website, } \\
\text { which is set to prepopulate with any Clearinghouse job vacancies. }\end{array}$ \\
\hline Services & $\begin{array}{l}\text { "Services We Offer" and six subpages that offer short descriptions that can sometimes } \\
\text { have an "infomercial" feel. Some have links to other pages on the website. They are } \\
\text { listed in the following order: } \\
\text { 1. Applied Research } \\
\text { 2. Curriculum Development - links to 'Learning Solutions' } \\
\text { 3. Learning Solutions - they use the ADDIE model } \\
\text { 4. Program Evaluation } \\
\text { 5. Program Implementation - links to "Program Implementation Toolkit" - links to } \\
\text { 6. 'Continuum of Evidence' database and "Program Implementation Toolkit" } \\
\text { All are also featured on the homepage, except 'Learning Solutions' is titled 'Instructional } \\
\text { Design.' }\end{array}$ \\
\hline
\end{tabular}


Table 1. (continued)

\begin{tabular}{|l|l|}
\hline Website section & \multicolumn{1}{c|}{ Brief description } \\
\hline Contact Us & $\begin{array}{l}\text { This is one of the most helpful features of the Clearinghouse website: Technical } \\
\text { assistance is available via "live chat," a toll-free phone helpline, and email. Live chat and } \\
\text { the toll-free line are staffed from 9 AM to } 5 \text { PM EST (closed for major holidays). These } \\
\text { allows users to connect with members of the team to ask questions or get more } \\
\text { information. }\end{array}$ \\
\hline
\end{tabular}

The "Program Reviews" section is one of the most robust on the Clearinghouse website. This link takes users to a substantial, searchable database, referred to as the "Continuum of Evidence." Clearinghouse staff reviewed prevention, treatment, and education programs to assess their effectiveness and potential benefit to military personnel and their families. As of December 2019, the "Continuum" included information about 1,328 programs. Program designations include effective, promising, unclear, and ineffective (see Figure 1). Table 2 provides more details about Continuum features.

Figure 1. Clearinghouse Program Effectiveness Continuum Descriptions

\begin{tabular}{|c|c|c|c|c|c|c|}
\hline $\begin{array}{c}\text { Effective } \\
\text { RCT }\end{array}$ & $\begin{array}{c}\text { Effective } \\
\text { Quasi }\end{array}$ & Promising & $\begin{array}{c}\text { Unclear } \\
+\end{array}$ & $\begin{array}{c}\text { Unclear } \\
\varnothing\end{array}$ & $\begin{array}{c}\text { Unclear } \\
\text { - }\end{array}$ & Ineffective \\
\hline $\begin{array}{l}\text { - Significant effects; and } \\
\text { - Effects lasting at least } \\
\text { one year from program } \\
\text { completion; and } \\
\text { - At least one successful } \\
\text { external replication; and } \\
\text { - Randomized controlled } \\
\text { study design; and } \\
\text { - Meets all additional } \\
\text { criteria. }\end{array}$ & $\begin{array}{l}\text { - Significant effects; and } \\
\text { - Effects lasting at least } \\
\text { one year from program } \\
\text { completion; and } \\
\text { - At least one successful } \\
\text { external replication; and } \\
\text { - Quasi-experimental study } \\
\text { design; and } \\
\text { - Meets all additional } \\
\text { criteria. }\end{array}$ & $\begin{array}{l}\text { - Significant effects. } \\
\text { - Randomized controlled or } \\
\text { quasi-experimental study } \\
\text { design. } \\
\text { - Effects lasting six months } \\
\text { from program completion; } \\
\text { or } \\
\text { - No evidence of successful } \\
\text { external replication; or } \\
\text { - Meets } 2 \text { or } 3 \text { additional } \\
\text { criteria. }\end{array}$ & $\begin{array}{l}\text { - Potentially promising } \\
\text { features. } \\
\text { - Effects lasting less than } \\
\text { six months from program } \\
\text { completion; or } \\
\text { - Pre-test/post-test study } \\
\text { design; or } \\
\text { - Meets } 0 \text { or } 1 \text { additional } \\
\text { criteria. }\end{array}$ & $\begin{array}{l}\text { - No evaluations or mixed } \\
\text { results across more than } \\
\text { one evaluation. }\end{array}$ & $\begin{array}{l}\text { - No significant effects } \\
\text { or significant negative } \\
\text { effects. }\end{array}$ & $\begin{array}{l}\text { - A program that meets } \\
\text { all criteria for an effective } \\
\text { placement but fails to } \\
\text { demonstrate a significant } \\
\text { effect, or demonstrates } \\
\text { significant negative } \\
\text { effects. }\end{array}$ \\
\hline
\end{tabular}

Source: Continuum of Evidence: Clearinghouse for Military Family Readiness (n.d.). 
Journal of Youth Development | http://jyd.pitt.edu/ | Vol. 15 Issue 5 DOI 10.5195/jyd.2020.918

Clearinghouse for Military Family Readiness

Table 2. Clearinghouse Website "Continuum of Evidence" Features

\begin{tabular}{|c|c|}
\hline Website feature & Brief description \\
\hline Search bar & Searches for all words entered. Use the "Filter Options" to refine the search. \\
\hline Filter options & $\begin{array}{l}\text { Nine filters help narrow and refine program searches: } \\
\text { 1. Program title } \\
\text { 2. Placement on continuum - effectiveness rating } \\
\text { 3. Topic - } 44 \text { subcategories } \\
\text { 4. Target audience }-19 \text { subcategories } \\
\text { 5. Sector }-6 \text { subcategories } \\
\text { 6. Military use } \\
\text { 7. Facilitator training }-9 \text { subcategories } \\
\text { 8. Implementation }-7 \text { subcategories } \\
\text { 9. Availability }\end{array}$ \\
\hline Results list & $\begin{array}{l}\text { Displays programs in an easy-to-read, color-coded by effectiveness rating list. } \\
\text { Information includes: } \\
\text { - Program name - also a link to more detailed program review fact sheet (see } \\
\text { below) } \\
\text { - Topic } \\
\text { - Target population } \\
\text { - Brief program description } \\
\text { Users can click the program name to open the full review fact sheet within the same } \\
\text { browser window and easily navigate back to the list by clicking the "Back" link, or } \\
\text { choose to click an icon to open it in a new browser tab, in which case users have to } \\
\text { navigate back to the full database by changing/clicking their web browser tabs. }\end{array}$ \\
\hline
\end{tabular}


Table 2. (continued)

\begin{tabular}{|c|c|}
\hline Website feature & Brief description \\
\hline $\begin{array}{l}\text { Program review } \\
\text { fact sheet }\end{array}$ & 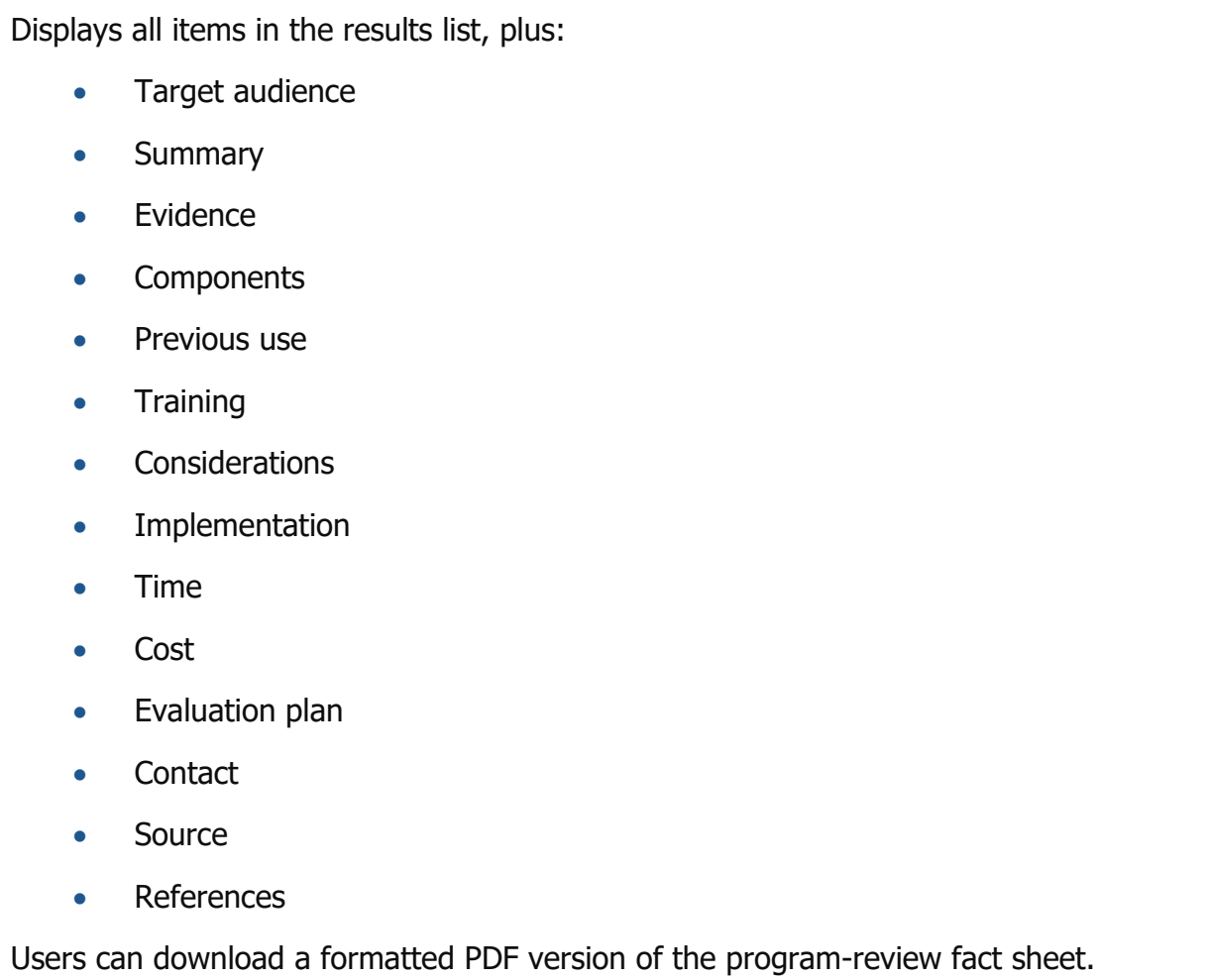 \\
\hline $\begin{array}{l}\text { Continuum } \\
\text { "About" page }\end{array}$ & $\begin{array}{l}\text { The "About" page provides more specifics, including links to documentation regrading } \\
\text { review criteria and a comparison of the Clearinghouse review process to those } \\
\text { conducted by other organizations/groups. Programs reviewed and included in the } \\
\text { database had evaluations published in peer-reviewed journals. Review criteria includes: } \\
\text { - Study design } \\
\text { - Representative sample } \\
\text { - Modest attrition } \\
\text { - Significant effects } \\
\text { - Sustained effects } \\
\text { - Outcome measures } \\
\text { - External replication } \\
\text { - Practical significance }\end{array}$ \\
\hline $\begin{array}{l}\text { Continuum } \\
\text { "Submit" page }\end{array}$ & $\begin{array}{l}\text { A "Submit" page provides information for users wishing to submit their program to the } \\
\text { Clearinghouse for review and inclusion in the Continuum database. }\end{array}$ \\
\hline
\end{tabular}

Another robust website section provides users with information and links to free online learning content, ready-to-use programs, resources, blogs, and other social media. See Table 3 for an overview of the "Resources" section. 
Table 3. Clearinghouse Website "Resources" Sections

\begin{tabular}{|c|c|}
\hline Website section & Brief description \\
\hline "Thrive!" & $\begin{array}{l}\text { Thrive is a set of parent-empowerment programs and resources to help military } \\
\text { parents ensure their children thrive. It includes four age-based modules: } \\
\text { - "Take Root!" 0-3 } \\
\text { - "Sprout!" 3-5 "Brow!" 5-10 } \\
\text { Each module focuses on three areas: positive parenting practices, parent and } \\
\text { child stress management, and strategies for promoting child physical health. } \\
\text { Thrive also offers a program for at-risk and high-needs populations. }\end{array}$ \\
\hline "5210" & $\begin{array}{l}\text { " } 5210 \text { " is a health promotion campaign program designed to spread simple } \\
\text { messages to help parents support their children's healthy eating and physical } \\
\text { activity. Each digit represents a health-promoting behavior: } \\
\text { - } 5 \text { or more servings of fruits and vegetables } \\
\text { - } \quad 1 \text { or fewer hours of recreational screen time } \\
\text { - } 0 \text { sweetened beverages } \\
\text { The program has civilian and military versions. The military version has many } \\
\text { resources tailored to the specific needs, circumstances, and living arrangements } \\
\text { of military families. }\end{array}$ \\
\hline
\end{tabular}


Table 3. (continued)

\begin{tabular}{|c|c|}
\hline Website section & Brief description \\
\hline $\begin{array}{l}\text { School resources for } \\
\text { military-connected } \\
\text { children }\end{array}$ & 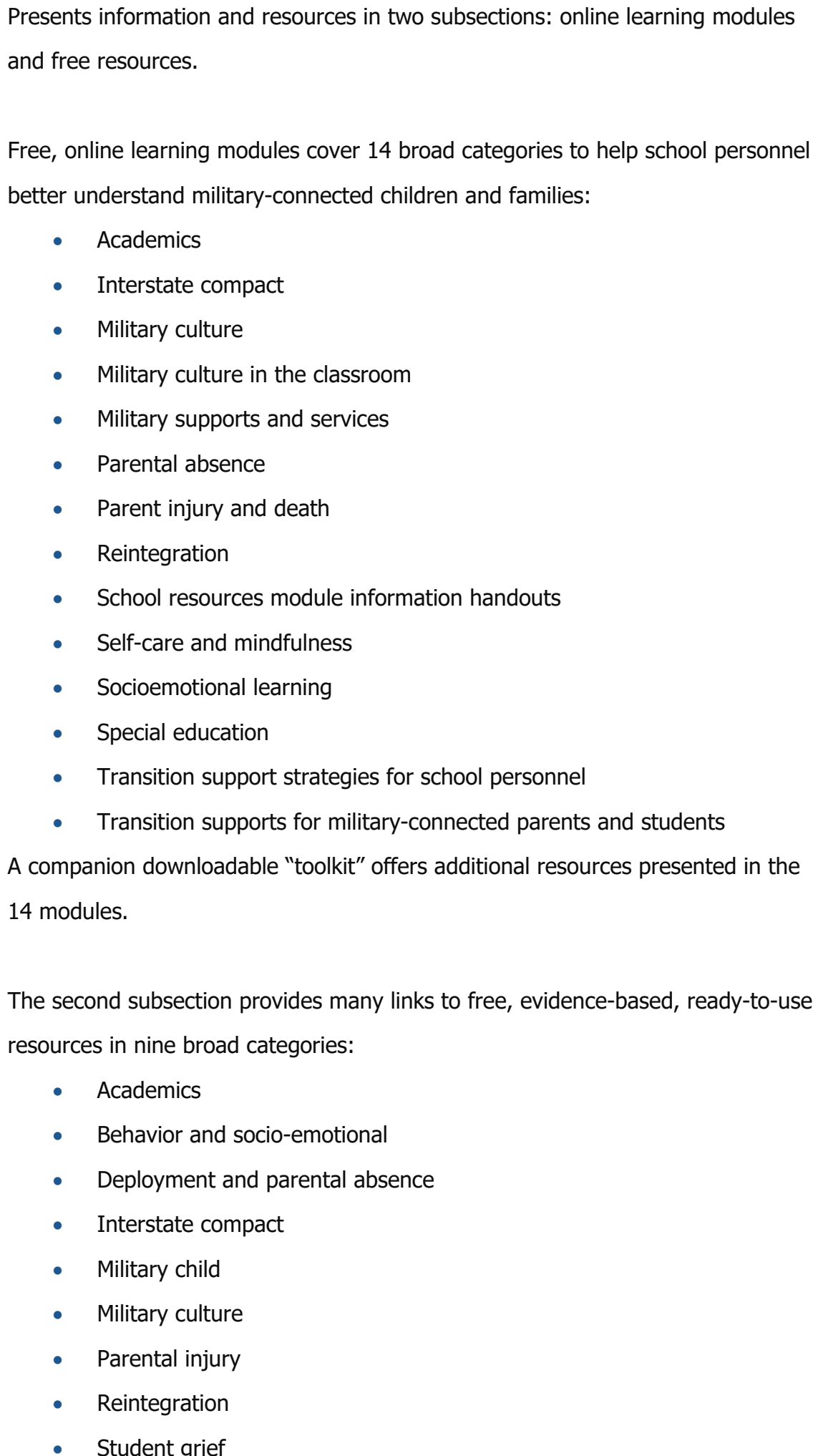 \\
\hline
\end{tabular}


Table 3. (continued)

\begin{tabular}{|c|c|}
\hline Website section & Brief description \\
\hline $\begin{array}{l}\text { Program } \\
\text { implementation } \\
\text { toolkit }\end{array}$ & $\begin{array}{l}\text { A set of evidence-informed, easy-to-use informational sheets, resource lists, } \\
\text { tools, and worksheets designed and curated to help professionals who work with } \\
\text { military families is grouped under five categories: } \\
\text { - Serving the military population (including veterans) } \\
\text { - Getting your community ready } \\
\text { - Choosing the right program } \\
\text { - Implementing a program with success } \\
\text { - Planning for program evaluation }\end{array}$ \\
\hline $\begin{array}{l}\text { Clearinghouse } \\
\text { publications }\end{array}$ & $\begin{array}{l}\text { Links to journal articles, reports, technical assistance rapid literature reviews, } \\
\text { videos, and infographics. Some links were broken, and some videos did not play. }\end{array}$ \\
\hline External resources & Provides links to three military-focused efforts. \\
\hline $\begin{array}{l}\text { National hotlines } \\
\text { and resources }\end{array}$ & 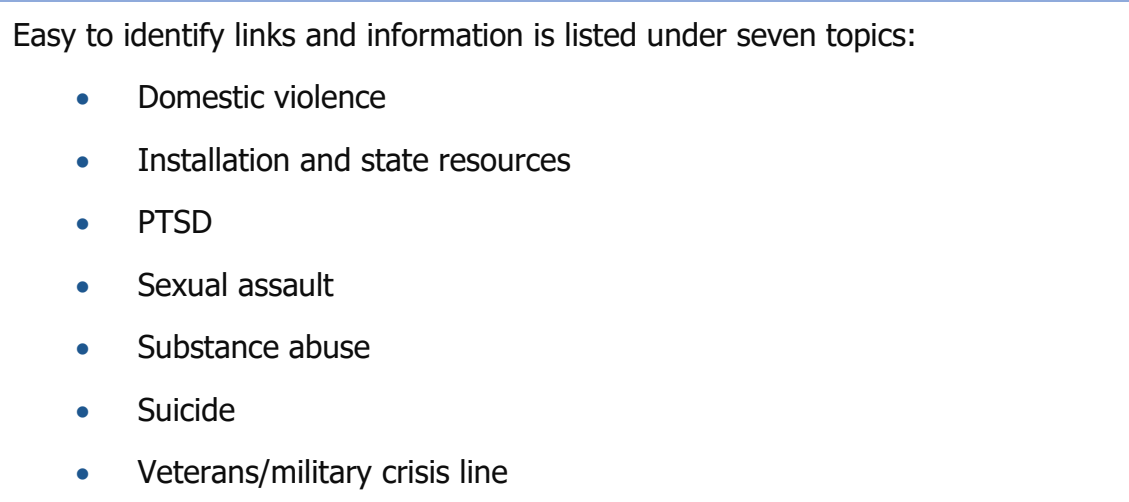 \\
\hline FAQ & $\begin{array}{l}\text { Several frequently asked questions provide additional information about the } \\
\text { Clearinghouse and the services it provides. }\end{array}$ \\
\hline
\end{tabular}

The "Projects" section of the website lists very brief descriptions of many current and completed projects. Although the list shows a breadth of partnerships and activities, it is not particularly helpful as no links to additional information are provided.

\section{Strengths and Considerations for Youth Development Professionals}

The following strengths and considerations are offered to professionals interested in using this resource:

- The Clearinghouse website is a one-stop shop for youth development professionals looking for effective programs and resources for working with military-connected families. 


\section{Clearinghouse for Military Family Readiness}

- The Continuum of Evidence database provides easy-to-use search and program information to help professionals identify and locate evidence-based programs.

- Clearinghouse resources include a user-friendly, free, program implementation toolkit and resources specifically for school personnel who work with children in military families. These include free online learning modules, access to webinars, videos, virtual learning communities, and social media networks.

- A few potential challenges of the "Program Implementation Toolkit" and other resources are that each component of the Toolkit is an individual download. It would be helpful to have an option to download it as one package, or as five downloads grouped by category. Additionally, the videos on "Clearinghouse Publications" page would benefit from titles and short overviews or introductions.

- A live chat and toll-free helpline provide convenient support for users of the website, as well as easy connection to the Clearinghouse's free technical assistance and coaching.

\section{Conclusion}

The primary focus of Clearinghouse efforts is to apply science to meet challenges identified by military partners. It exists to increase professionals' capacity to strengthen military family readiness, resilience, and overall well-being. The Clearinghouse is successful in achieving its stated mission: It is a comprehensive, trusted, easy-to-navigate source of evidence-based, and evidence-informed resources, technical assistance, and support that helps professionals who assist military families do that work more effectively and with confidence.

\section{How to Access}

Professionals can access this resource at https://militaryfamilies.psu.edu.

\section{References}

Ames, B., Smith, S., Holtrop, K., Blow, A., Hamel, J., MacInnes, M., \& Onaga, E. (2011). Meeting the needs of National Guard and Reserve families: The vital role of Extension. Journal of Extension, 49(5), Article 5FEA7. http://www.joe.org/joe/2011october/a7.php

Clary, C., \& Ferrari, T. (2015). Communication, coping, and connections: campers' and parents' perspectives of self-efficacy and benefits of participation in deployment support camps. Journal of Youth Development, 10(2), 31-54. https://doi.org/10.5195/iyd.2015.407 
Journal of Youth Development | http://jyd.pitt.edu/ | Vol. 15 Issue 5 DOI 10.5195/jyd.2020.918

Clearinghouse for Military Family Readiness

Continuum of Evidence: Clearinghouse for Military Family Readiness. (n.d.). https://www.continuum.militaryfamilies.psu.edu/about

Defense Manpower Data Center. (2019, November). Number of military and DoD appropriated fund (APF) civilian personnel permanently assigned by duty location and service/component. DRS \# 103763. https://www.dmdc.osd.mil/appj/dwp/rest/download?fileName=DMDC Website Location Report 1909. xlsx\&groupName=milRegionCountry

Department of Defense, Office of the Deputy Assistant Secretary of Defense for Military Community and Family Policy. (2018). 2018 Demographics: Profile of the military community. https://download.militaryonesource.mil/12038/MOS/Reports/2018-demographics-report.pdf

Ferrari, T. (2015). Considerations for creating successful camps for military families. Journal of Extension, 49(5), Article 5IAW6. https://www.joe.org/joe/2015october/iw6.php

Hawkins, S., Condon, A., Hawkins, J., Liu, K., Ramirez, Y., Nihill, M., \& Tolins, J. (2018). What we know about military family readiness: Evidence from 2006-2017. Research Facilitation Laboratory, Army Analytics Group, Office of the Deputy Under Secretary of the Army. https://apps.dtic.mil/dtic/tr/fulltext/u2/1050341.pdf

Huebner, C. R. (2019). Health and mental health needs of children in US military families. Pediatrics, 143(1), e20183258. https://doi.org/10.1542/peds.2018-3258

Mogil, C., Heiselberg, M. H., Clement, A., \& Nielsen, A. B. S. (2019). Programs for children in military families. Journal of Military, Veteran and Family Health, 5(S2), 97-115. https://doi.org/10.3138/jmvfh.2019-0011

National Academies of Sciences, Engineering, and Medicine. (2019). Strengthening the military family readiness system for a changing American society. The National Academies Press. https://doi.org/10.17226/25380

Sullivan, R. M., Cozza, S. J., \& Dougherty, J. G. (2019). Children of military families. Child and Adolescent Psychiatric Clinics, 28(3), 337-348. https://doi.org/10.1016/j.chc.2019.02.004 